the shelter occupants must be in receipt of their due meed of skilled supervision. This supervision is the work of the general practitioner, of the nurse, and of the tuberculosis officer; and, in proportion as it is efficient, sympathetic, and painstaking. or the reverse of these, so will the "results obtained " give cause for satisfaction or provide food for regretful thought.

\section{NOTES ON AN}

INTERESTING MILK PROSECLTION.

BY JAMES DUND.AS, M.D., D P.H.,

Medical Officer of Hea'th, Ramsgate.

$T^{\mathrm{H}}$ $\mathrm{HE}$ case is interesting as it exemplifies the need for an amendment in the law on the lines laid down in Clause 25 of the Milk and Dairies Pill of last session.

The facts are briefly as follows:-On October I 5 th, I913, the :inspector under the Food and Drugs Acts for this district (Ramsgate) purchased a sample of milk from a man named Hoyle, a servant of Messrs. G. \& H. Darby, well known farmers in the borough. On analysis the milk was found to contain 14.6 per cent. added water and to be deficient in fat to the extent of 6.7 per cent. The facts were reported to the Sanitary Committee, who ordered a prosecution under Sec. 6 of the liood and Drugs Acts, $18_{75}$. As the inspector and myself were both satisfied from our knowledge of Messrs. G. \& H. Darby personally, and of their manner of conducting their trade, that they were morally innocent though possibly guilty of a technical offence in selling milk adulteraled with water, I sent for one of the brothers, who assured me of their innocence. Arrangements were then made between Mr. Darby and the inspector, whereby the former on a pre-arranged morning would take a sample of milk from his churns immediately prior to their despatch from the farm and the latter would take a series of samples on the same morning in order, if possible, to detect the culprit. There was some difficulty in this matter, as all the milk produced on the farm was sent in charge of the nephew of one of the defendants and the son of the orher to a certain point in the town where hand pails were filled from the churns. Several men proceeded with these to different quarters of the town.

I Before, however, these arrangements could be carried out the two brothers assumed the role of Sherlock Holmes on their own account. On talking the matter over they had formed the opinion that the milk was watered in the cowshed from a standpipe there. Accordingly late at night they gently inserted into the tap a small scrap of paper so marked as to be readily identified. On the following morning they found this scrap of paper in the milk strainer. It should be stated that the practice on this farm is to strain all the milk in bulk into large churns and forthwith to despatch it to the town. One of the brothers immediately came to see me, and I arranged that Detective-Inspector Duff should join Messrs. Darby about three o'clock on the following morning, October 24th, the intention being that they should secrete themselves in a shed separated by a partition from the cowshed of which they would be able to get a good view. This plan was nearly frustrated by the cackling of ducks and geese, which prored better "watches" than the farm dogs. However, safely ensconced in the shed the detective and Messrs. Darby were able to watch the two cowmen at work. One of these soon had filled his pail and left the shed to take it to the dairy where the milk is strained. The other man immediately went to the standpipe and ran water into his milk pail until he heard the returning footsteps of his fellow, when he quietly resumed his task of milking. The detective and Messrs. Darby at once accosted the cowman, Sayer, who, after at first denying that he had added water to the milk, admitted having done so for the reason that the milk was running short. He was immediately discharged.

The summonses against Messrs. Darby had been made returnable on Novemuer i4th.

Messrs. Darby, on the advice of their solicitor, took out a summons against Sayer under the Malicious Damage Act, $186 \mathrm{I}$, Sec. 2., and this summons was also made returnable on November $\mathrm{I}_{4} \mathrm{th}$.

The case of Darby $v$. Sayer was heard first. The defendant pleaded "guilty." In his opening speech the agent for the prosecution stated that the case Roper $v$. Knott, heard before the Queen's* Bench Division, was on all fours with the present one, save that in the former case the defendant sold the milk for his own benefit whereas in this case there was no apparent motive for the offence. Lord Justice Blackburn, in giving judgment in Roper v. Knott, held that malicious damage was "damage to another without lawful excuse," and that in the present case damage was caused for which there was no reason or excuse whatever. In reply to the Bench, the defendant stated that he feared to be blamed for the milk getting short and had, therefore, made up the deficiency with water. In view of the severe punishment the defendant had already suffered-loss of good employment-and their opinion that the act of the defendant was the result of sheer stupidity, the Bench decided to inflict a nomiual penalty, Ios. including costs.

In view of this decision the inspector, who prosecuted in the case under the Food and Drugs Acts against Darby, proved his case and then asked that it might be dismissed with costs-a proposal to which the Bench agreed.

*(1898) 1 Q.B. $86 \%$; 62 J.P. $375 ; 67$ L.J., Q.B. $574 ; 78$ L.T. $595 ; 14$. L.R., T. 343 . 